\title{
Penerapan Metode Debat Aktif untuk Meningkatkan Kemampuan Berdiskusi Mahasiswa dalam Pembelajaran Konsep Dasar PKn di PGSD UPP Bone FIP UNM
}

\author{
Makmur Nurdin \\ UPP PGSD Bone, Fakultas Ilmu Pendidikan, UNM \\ makmur.nurdin@unm.ac.id
}

\begin{abstract}
ABSTRAK
Tujuan penelitian ini untuk : 1) Mendeskripsikan penerapan metode debat aktif dalam proses pembelajaran konsep dasar PKn. 2) Meningkatkan kemampuan berdiskusi mahasiswa PGSD UPP Bone dalam pembelajaran konsep dasar PKn melalui penerapan metode debat aktif. Pendekatan penelitian ini adalah kualitatif dengan jenis penelitian tindakan kelas. Subyek dalam penelitian ini adalah mahasiswa D 24 B di PGSD UPP Bone FIP UNM yang berjumlah 30 orang. Teknik pengumpulan data menggunakan teknik observasi, wawancara dan dokumentasi. Hasil penelitian adalah sebagai berikut: 1) Penerapan metode debat aktif dalam pembelajaran konsep dasar PKn mendorong mahasiswa lebih aktif dalam diskusi karena setiap mahasiswa diberi kesempatan untuk berbicara dan berargumen. 2) Penerapan metode debat aktif dapat meningkatkan kemampuan diskusi mahasiswa dalam pembelajaran Konsep Dasar PKn, pada siklus I yaitu 63,09\% (19 mahasiswa) aktif dengan kategori sedang, pada siklus II meningkat menjadi 89,97\% (27 Mahasiswa) aktif dalam kategori tinggi.
\end{abstract}

Kata kunci: Metode Debat Aktif, Kemampuan Berdiskusi

\section{PENDAHULUAN}

Pendidikan Kewarganegaraan (PKn) merupakan salah satu bentuk pendidikan yang secara intensif membentuk karakter, nilai, moral, dan sikap perilaku peserta didik dalam rangka membantu memanusiakan manusia (Komalasari, 2014). PKn telah direorganisasi menjadi kurikulum pendidikan dasar disetiap jenjang Pendidikan baik dari tingkat SD, SMP, SMA sampai pada tingkat perguruan tinggi (Eurydice, 2005). PKn telah didefinisikan sebagai suatu hak istimewa bagi seluruh warga Negara dalam mengembangkan dan melaksanakan kewarganegaraan (Nogueira, 2011). PKn diharapkan dapat memberikan sudut pandang transdisipliner (sebuah komponen yang berjalan di semua mata pelajaran kurikulum yang menekan pada tiga aspek yaitu pengetahuan, sikap dan keterampilan warga Negara), Hal ini sebagaimana tertuang dalam undang-undang lama yaitu undang-undang nomor 2 tahun 1989 tentang sistem pendidikan nasional. Selanjutnya tetap dipertahankan sebagai pendidikan wajib menurut ketentuan baru undang-undang sistem pendidikan nasional yaitu undang-undang nomor 20 tahun 2003 tentang sistem pendidikan nasional.

Tujuan PKn pada dasarnya adalah menjadikan warga negara yang baik, cerdas serta berupaya untuk mempromosikan pengayaan global siswa agar berpartisipasi aktif dalam kehidupan bermasyarakat sebagai warga negara yang mampu bertanggung jawab terhadap diri sendiri masyarakat, bangsa dan negara (Thorsten Bohl,2013). PKn juga memiliki tujuan menanamkan nilai-nilai demokrasi, tanggung jawab, kerja sama yang baik sehingga nantinya siswa sebagai warga negara akan berperan aktif dalam masyarakat (Tesfaye Semela, 2013). Guna mencapai tujuan tersebut maka pengondisian lingkungan Pendidikan harus dilakukan secara komprehensif. Pengembangan sikap demokrasi harus dilakukan secara terus menerus, karena proses mengubah performasi tidak terbatas pada pengetahuan tetapi juga meliputi ketrampilan, persepsi, emosi dan proses berfikir logis. Pengembangan sikap demokratis salah satunya dapat dikembangkan dari ketrampilan diskusi.

Tarigan (2008) menjelaskan bahwa diskusi adalah metode pemecahan masalah dengan perfikir secara kelompok. Diskusi juga bisa dimaknai sebagai suatu kegiatan kerjasama atau aktifitas koordinatif yang mengandung langkah-langkah dasar tertentu yang harus dipatuhi oleh seluruh kelompok. Diskusi pada dasarnya merupakan suatu bentuk tukar pikiran yang teratur dan terarah baik dalam kelompok kecil maupun dalam kelompok besar dengan tujuan untuk 
mendapatkan suatu pengertian, kesepakatan, dan keputusan bersama mengenai suatu masalah (Nur Chabibah:2011). Berdasarkan beberapa pendapat diatas dapat disimpulkan bahwa diskusi adalah metode pemecahan masalah melalui tukar pikiran yang terstruktur dan terarah dalam suatu kelompok.

Kegiatan diskusi juga memiliki fungsi untuk berfikir logis dan mengeluarkan pendapatnya sendiri mencakup persoalanpersoalan yang tidak dapat dipecahkan hanya satu jawaban tetapi memerlukan wawasan pengetahuan yang mampu mencari jawaban atau jalan terbaik hasil berfikir logis dan sistematis dari sebuah masalah. Melalui diskusi beberapa karakter yang dapat dikembangkan antara lain, mengemukakan dan menerima pendapat orang lain, keberanian mengemukakan ide dan gagasan ,berfikir kritis, sistematis, pengendalian diri, toleransi, kerja sama, dan partisipasi. Namun tujuan dan fungsi dari diskusi terkadang terhambat oleh beberapa kendala dari penerapan metode diskusi ini. Kendala yang dialami oleh Dosen dalam menerapkan metode ini diantaranya adalah dominasi mahasiswa tertentu yang paham akan pokok bahasan dan mereka yang mempunyai kepercayaan diri tinggi. Sedangkan mahasiswa yang lain cenderung diam karena merasa kurang percaya diri dalam mengutarakan pendapat, ide maupun alternatif pemecahan yang dimilikinya.

Menyikapi permasalahan diatas diperlukan metode diskusi yang tepat dan mampu menstimulus mahasiswa untuk berkontribusi. Salah satu strategi pembelajaran yang sesuai dengan implikasi pembelajaran PKn khususnya Konsep Dasar PKn yang dapat mengatasi kurang aktifnya mahasiswa dalam diskusi adalah dengan menggunakan metode debat aktif. Penggunaan metode debat aktif dapat menstimulus mahasiswa untuk berperan aktif dalam berkomunikasi baik antar mahasiswa maupun komunikasi dengan dosen. Kebiasaan berperan aktif dan berkomunikasi dalam pembelajaran akan membiasakan mahasiswa untuk terbiasa ikut perpartisipasi dalam menjalankan kehidupan bermasyarakat, berbangsa dan bernegara sebagai warga negara yang baik.

Metode debat Aktif merupakan salah satu metode yang diciptakan oleh Malvin L Sibermen dalam pembelajaran aktif (Aktive Learning). Metode ini digunakan untuk menstimulasi diskusi kelas. Melalui metode debat Aktif mahasiswa didorong untuk mengemukakan pendapatnya melalui suatu perdebatan antar kelompok diskusi yang disatukan dalam sebuah diskusi kelas. Debat merupakan suatu argumen untuk menentukan baik tidaknya suatu usul tertentu yang didukung oleh suatu pihak yang disebut pendukung atau afirmatif, dan ditolak, disangkal oleh pihak lain yang disebut penyangkal atau negatif ( Tarigan, $1984: 86$ ). Sementara menurut Kamdhi (1995:24-26) debat adalah suatu pembahasan atau pertukaran pendapat mengenai suatu pokok masalah dimana masing-masing peserta memberikan alasan untuk mempertahankan pendapatnya.

Diskusi kelompok mampu memberikan sumber-sumber yang lebih banyak bagi pemecahan masalah (Problem Solving) dibanding yang tersedia atau yang diperoleh, apabila pribadi yang membuat keputusan yang mempengaruhi suatu kelompok. Diskusi juga sangat berguna apabila pandangan yang bertentangan harus diajukan dan suatu hasil yang bersifat memilih salah satu dari dua hal yang segera akan dilaksanakan (Tarigan, 2008). Nurchabibah (2011) menyatakan bahwa penggunaan penilaian keterampilan diskusi berdasarkan kriteria factor penunjang keefektifan berbicara yang antara lain: a) memberikan pendapat, b) Menerima pendapat orang lain, c)Menanggapi pendapat orang lain, d) Kemampuan mempertahankan pendapat, e) Kelancaran berbicara, f) Kenyaringan suara, g) Keberanian berbicara, h) Ketepatan struktur kosa kata,i) Pandangan mata dan j) Penguasaan topik.

PKn diartikan sebagai mata kuliah yang memfokuskan pada pembentukan warga Negara yang memahami dan mampu melaksanakan hak-hak dan kewajibannya untuk menjadi warga Negara Indonesia yang cerdas, terampil dan berkarakter yang dimanatkan oleh pancasila dan UUD 1945 (Winarno,2013). Selanjutnya tujuan dari pembelajaran PKn adalah agar peserta didik memiliki kemampuan untuk berpikir secara kritis, rasional, dan kreatif dalam menanggapi isu kewarganegaraan, berpartisipasi secara aktif dan bertanggung jawab dan bertindak secara cerdas, berkembang secara positif dan demokratis serta berinteraksi dengan bangsabangsa lain dalam percaturan dunia.

PKn mempunyai tiga kompetensi dasar yang harus dimilki oleh warga negara Indonesia yaitu: civic knowledge, civic skill, civic disposition (Ubaedillah,2015). Civic knowledge yaitu pengetahuan yang yang harus diketahui atau dimiliki oleh warga negara tentang negaranya. Civic skill yaitu 
keterampilan yang harus dimiliki oleh warga negara, keterampilan itu meliputi: keterampilan dalam memecahkan suatu permasalahan sosial yang ada dalam negara, keterampilan intelektual, keterampilan sikap dan keterampilan berpartisipasi. Civic disposition yaitu berkaitan dengan karakter privat dan publik dari warga negara yang perlu dipelihara dan ditingkatkan dalam demokrasi.

\section{METODE PENELITIAN}

Pendekatan penelitian yang digunakan pada penelitian ini adalah pendekatan kualitatif. Jenis penelitian yang dipilih adalah penelitian tindakan kelas (PTK). PTK merupakan suatu pencermatan secara mandalam terhadap sebuah kegitan belajar dalam bentuk tindakan yang sengaja dimunculkan dan terjadi dalam sebuah kelas secara bersama (Arikunto, 2014). Penelitian ini difokuskan pada 1) penerapan metode debat aktif dalam proses pembelajaran PKn. 2) kemampuan berdiskusi mahasiswa dalam pembelajaran konsep dasar PKn melalui penerapan metode debat aktif. Penelitian ini dilaksanakan di kampus PGSD UPP Bone FIP UNM dan Subjek penelitian adalah mahasiswa kelas D 24 B yang berjumlah 30 orang. Teknik pengumpulan data yang digunakan dalam penelitian ini adalah pengambilan data dengan observasi (Pengamatan), wawancara dan Studi Dokumen. Adapun tahapan dalam penelitian ini mengacu pada Model Kemmis dan Mc Taggart (Hopkins, 2008) yang terdiri dari 4 komponen yaitu: rencana tindakan (planning), tindakan (acting), pengamatan (observing) dan refleksi (reflecting). Keempat komponen yang berupa untaian tersebut dipandang sebagai satu siklus PTK. Langkah-langkah penelitian untuk setiap siklus dalam penelitian ini dapat diilustrasikan dalam siklus sebagai berikut:

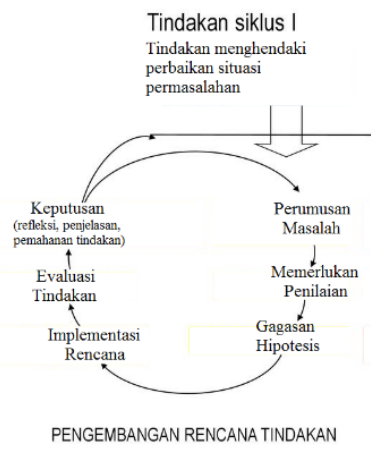

T1
Tindakan siklus ||

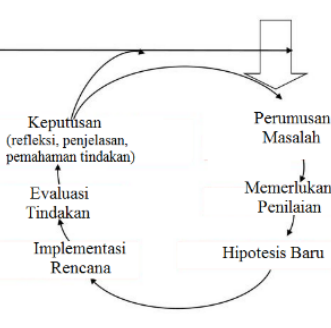

REVISI RENCANA TINDAKAN T2

Gambar 1. Desain Penelitian Tindakan Kelas (Hopkins, 2008: 53)

Teknik analisis data kualitatif mengacu pada model analisis Miles dan Huberman

(Sugiyono, 2010) yang dilakukan dalam empat tahap yaitu 1) Pengumpulan Data, 2)Reduksi data, 3) Penyajian data dan 4) Penarikan kesimpulan dan verifikasi. Adapun skema dari pemeriksaan analisis data yang digunakan dapat dilihat dalam gambar berikut:

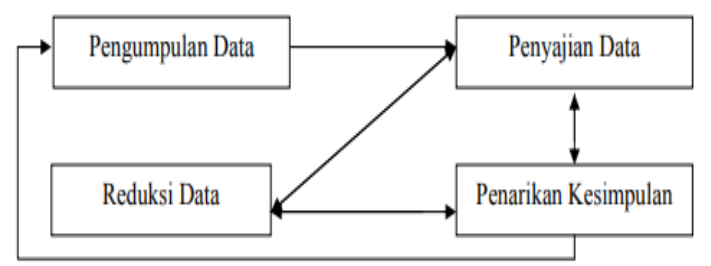

Gambar 2. Skema analisis data

\section{HASIL \& PEMBAHASAN}

Hasil observasi pada pertemuan siklus 1 diperoleh presentase ketercapaian yaitu : Terdapat 17 orang mahasiswa (52,78 \%)yang skornya tergolog dalam kategori rendah, 8 orang mahasiswa $(27,78 \%)$ tergolong dalam kategori cukup, dan 5 orang mahasiswa $(19,44$ \%) tergolong dalam kategori tinggi. Hasil evaluasi pada proses pembelajaran pada siklus 1 menunjukkan bahwa sepuluh indikator ketercapaian kinerja yang telah ditetapkan belum tercapai. Berdasarkan hasil yang diperoleh dapat disimpulkan bahwa kemampuan mahasiswa dalam berdiskusi melalui metode debat aktif tentang pelaksanaan Demokrasi di Indonesia dapat dilihat pada tebel 1 berikut:

Tabel 1. Data hasil diskusi materi Pelaksanaan Demokrasi di Indonesia

\begin{tabular}{|c|c|c|c|c|}
\hline No & Skor & $\mathrm{F}$ & $\%$ & Keterangan \\
\hline 1 & $<70$ & 16 & 52,78 & $\begin{array}{c}\text { Kurang } \\
\text { mampu }\end{array}$ \\
\hline 2 & $\geq 70$ & 14 & 47,22 & mampu \\
\hline & Jumlah & 30 & 100 & $\begin{array}{c}\text { Tindakan } \\
\text { dilanjutkan }\end{array}$ \\
\hline
\end{tabular}

Dari data tabel 1 diatas dapat disimpulkan bahwa 16 orang mahasiswa dapat dikategorikan belum mampu berdiskusi dengan baik, sedangkan 14 orang mahasiswa sudah dapat dikategorikan mampu berdiskusi dengan baik. Mengacu pada hasil diatas maka dilakukan pertemuan ke dua pada siklus 1 dihari senin tanggal 9 Juni 2015 dengan materi yang berbeda yaitu pelaksanaan HAM di Indonesia. berdasarkan hasil pertemuan ke 2 pada siklus 1 diperoleh data seperti pada tabel 2 dibawah ini : 
Tabel 2. Data hasil diskusi materi

Pelaksanaan HAM di Indonesia

\begin{tabular}{|c|c|c|c|c|}
\hline No & Skor & f & $\%$ & Keterangan \\
\hline 1 & $<70$ & 11 & 38,88 & $\begin{array}{c}\text { Kurang } \\
\text { mampu }\end{array}$ \\
\hline 2 & $\geq 70$ & 19 & 61,12 & mampu \\
\hline & Jumlah & 30 & 100 & $\begin{array}{c}\text { Tindakan } \\
\text { dilanjutkan }\end{array}$ \\
\hline
\end{tabular}

Tabel diatas menunjukkan bahwa 11 orang mahasiswa $(38,88 \%)$ dapat dikategorikan belum mampu berdiskusi dengan baik, sedangkan yang sudah mampu berdiskusi dengan baik adalah 19 orang mahasiswa $(61,12 \%)$. Data diatas menjadikan rujukan dalam pengambilan keputuasan terkait ketuntasan mahasiswa dalam melaksanakan metode diskusi, dikarenakan presentase kemampuan mahasiswa belum mencapai $70 \%$. Hasil evaluasi dan observasi pada pelaksnaan tindakan siklus 1 belum mencapai indikator kinerja yang telah ditetapkan dan belum sesuai dengan apa yang diharapkan dalam rencana program pembelajaran maka tindakan dilanjutkan pada siklus berikutnya. Adapun hal-hal yang masih perlu diperbaiki pada tindakan selanjutnya adalah sebagai berikut: Penguasaan topik pembicaraan, Logika berfikir dan realitas berargumen, ketepatan berargumen, keberanian mengajukan pendapat dan menanggapi pendapat orang lain, kemampuan mempertahankan pendapat, Kelancar berbicara, dan mengurangi rasa grogi. Penggunaan waktu dengan tepat, agar semua komponen dalam diskusi dapat terlaksana dengan baik.

Kegiatan siklus ke II, dilaksanakan pada hari senin Tanggal 16 Juni 2015 yang diikuti oleh 30 orang mahasiswa. Hal-hal yang di observasi pada pelaksanaan siklus II adalah proses pelaksanaan pembelajaran yang dilakukan oleh dosen apakah sesuai dengan rancangan tindak lanjut serta rencana pembelajaran yang telah dikembangkan serta tingkat perubahan kemampuan berdiskusi mahasiswa dengan perlakukan yang berbeda. Hasil observasi terhadap dosen dan mahasiswa menunjukkan hal-hal sebagai berikut: Mahasiswa antusias mengikuti debat karena penguasaan topik pembicaraan, logika berfikir dan realitas berargumen cukup baik. Ketepatan berargumen sudah kategori baik, karena hampir keseluruhan mahasiswa berani mengajukan pendapat dan menanggapi pendapat orang lain berdasarkan argumen dan berfikir logis. Kemampuan mahasiswa dalam mempertahankan pendapatnya dapat dikategorikan baik. Mahasiswa secara keseluruhan sudah mulai berani berbicara, dan berargumen dengan tepat serta tidak ada lagi rasa grogi. Pelaksanaan pembelajaran oleh dosen sangat baik karena keseluruhan pelaksanaan pembelajaran telah sesuai dengan rancangan refleksi yang telah ditentukan serta mampu berimprofisasi dengan baik mengacu pada refleksi kegiatan siklus I.

Berdasarkan hasil observasi selama pelaksanaan siklus II, perolehan skor diskusi dapat diketahui persentase ketercapaiannya. Terdapat 8 orang mahasiswa $(27,28 \%)$ masuk dalam kategori rendah, dan 12 orang mahasiswa $(38,88 \%)$ masuk dalam kategori cukup, serta 10 orang mahasiswa $(33,34 \%)$ masuk dalam kategori tinggi. kemampuan mahasiswa dalam berdiskusi melalui metode debat aktif tentang pelaksanaan Otonomi Daerah khususnya pada pokok bahasan tentang larangan merokok secara keseluruhan berdasarkan ketuntasan belajar dapat diurutkan dalam tabel sebagai berikut:

Tabel 3. Data hasil diskusi tentang Perda Larangan Merokok

\begin{tabular}{|c|c|c|c|c|}
\hline No & Skor & f & $\%$ & Keterangan \\
\hline 1 & $<70$ & 7 & 27,78 & $\begin{array}{c}\text { Kurang } \\
\text { mampu }\end{array}$ \\
\hline 2 & $\geq 70$ & 23 & 72,22 & mampu \\
\hline & Jumlah & 30 & 100 & $\begin{array}{c}\text { Tindakan } \\
\text { dilanjutkan }\end{array}$ \\
\hline
\end{tabular}

Berdasarkan hasil evaluasi dan observasi pada pelaksnaan tindakan siklus II menunjukkan bahwa:

1. Secara umum proses pembelajaran melalui diskusi debat akif, dapat berjalan dengan lancar sesuai dengan rencana pembelajaran yang telah ditentukan.

2. Selama kegiatan diskusi berlangsung, mahasiswa sudah berani berbicara, mengajukan pendapat / menjawab pertanyaan maupun mengajukan pertanyaan serta menghargai argumen temannya.

3. Dalam diskusi kelompok, mahasiswa sudah mampu membagi peran semua anggota kelompok dengan baik sehingga semua anggota kelompok aktif mengerjakan tugas sesuai dengan bagian yang didapat.

4. Pada saat pembelajaran berakhir mahasiswa sudah berani berbicara, mengajukan pendapat dan menyampaikan kesimpulan diskusi. 
5. Perolehan skor aktivitas pada siklus II meningkat dari pada skor pada tindakan siklus I.

Karena pelaksanaan diskusi sudah mencapai indikator kinerja yang telah ditetapkan dan sudah sesuai dengan apa yang diharapkan dalam rencana program pembelajaran maka tindakan tidak dilanjutkan lagi. Penelitian dihentikan pada siklus kedua ini karena indikator penelitian sudah tercapai.

Pembahasan

Penelitian ini mengangkat dua permasalahan, dan untuk memecahkan masalah tersebut telah dilaksanakan pada dua siklus penelitian. Penelitian ini dilaksanakan selama kurang lebih tiga bulan yaitu dari bulan Juni sampai bulan Agustus 2015 yang bertempat di kampus PGSD UPP Bone FIP UNM. Pelaksanaan siklus I dalam penelitian ini dilakukan dalam dua kali pertemuan. Adapun hasil observasi tentang permasalahan yang ditemui selama proses pembelajaran adalah sebagai berikut: Mahasiswa tidak sepenuhnya menguasai topik pembicaraan, logika berfikir dan realitas berargumen mahasiswa masih kurang, Ketepatan berargumen dapat dikategori cukup, Hanya sebagian mahasiswa yang mengajukan pendapat dan menanggapi pendapat orang lain.

Kemampuan mempertahankan
pendapat dapat dikategorikan cukup, dikarenakan mahasiswa belum yakin ketika menyampaiakan pendapat. Penguatan yang diberikan dosen setelah perdebatan selesai tidak tuntas dikarenakan waktu debat tidak dibatasi, sehingga waktu tidak terkontrol. Kendalakendala lain yang muncul selama pelaksanaan siklus 1 adalah :

1. Pemahaman mahasiswa pada pokok bahasan depat masih minim, sehingga dalam debat tidak ditemukan alternatif solusi maupun alur berfikir logis dalam mengutarakan pendapat. Sehingga perlu diberikan waktu pada mahasiswa sebelum debat berlangsung untuk membaca dan memahami materi terkait materi pelajaran yang akan dijadikan topik debat. Minimnya penguasaan materi juga akan berpengaruh pada pemahaman materi berikutnya.

2. Manajemen waktu dalam penggunaan metode debat aktif yang tidak baik membuat setiap tahapan proses pembelajaran terkesan tidak seimbang. sehingga sangat diperlukan managemen waktu yang ketat dan kemampuan dalam mengatur alur debat sehingga proses debat bisa berlangsung baik dan menyenangkan.

Pelaksanaan siklus II dilakukan satu kali pertemuan, Adapun hasil observasi yang ditemui selama proses pembelajaran adalah sebagai berikut: Secara umum proses pembelajaran dapat berjalan dengan lancar sesuai dengan rencana, Selama kegiatan diskusi berlangsung, mahasiswa sudah berani berbicara atau mengajukan pendapat dan menjawab pertanyaan maupun mengajukan pertanyaan, Dalam diskusi kelompok mahasiswa sudah mampu membagi tugas dengan baik sehingga semua anggota kelompok aktif mengerjakan tugas sesuai dengan bagian yang didapatnya. Pada saat pembelajaran berakhir mahasiswa sudah berani berbicara, mengemukakan pendapat dan menyampaikan kesimpulan .Perolehan skor aktivitas pada siklus II meningkat dari skor pada Tindakan siklus 1 .

Peningkatan perolehan skor kemampuan berdiskusi mahasiswa dari siklus 1 ke siklus II menunjukkan adanya perbedaan perolehan aktivitas diskusi yang cukup tinggi. Pada siklus I tingkat pencapaian ketuntasan klasikal mahasiswa belum mencapai target yang ditetapkan yaitu $70 \%$ sehingga belum opimal. Sedangkan pada siklus II telah terjadi peningkatan dengan perolehan tingkat klasikal tuntas. Peningkatan kemampuan berdiskusi mahasiswa nampak dari kualitas proses pembelajaran yang ditunjukkan oleh keaktifan interaksi, sikap dan antusias mahasiswa dalam melaksanakan diskusi. Kegiatan diskusi dengan menggunakan metode debat aktif dapat menciptakan Susana diskusi menjadi aktif dan menyenangkan bagi mahasiswa sedangkan bagi dosen dapat lebih mudah membimbing mahasiswa.

Pembagian kelompok yang setuju dan tidak setuju mampu menstimulus mahasiswa untuk lebih aktif dan berfikir logis untuk mempertahankan pendapatnya sesuai dengan posisi mereka. Pembagian tugas dan kapasitas dalam berbicara membuat mereka harus berfikir secara sistematis supaya mampu menunjukkan bahwa argumennya adalah benar dan disertai alur berfikir yang logis disertai fakta dan bukti pendukung. Metode debat aktif ini dapat memicu keberanian mahasiswa untuk dapat berbicara , menyampaikan pendapat, menanggapi pendapat yang lain, mempertahankan pendapat sehingga mahasiswa secara maksimal aktif dalam diskusi. Selain itu diskusi kelas tidak lagi didominasi oleh beberapa orang mahasiswa, karena mahasiswa yang lain pun diberi 
kesempatan menjadi juru bicara pada kegiatan diskusi melalui metode debat aktif. Penerapan metode debat aktif dapat dikatakan sangat efekif untuk meningkatkan kemampuan berdiskusi mahasiswa.

\section{KESIMPULAN \& SARAN}

Berdasarkan hasil kajian diatas maka dapat ditarik kesimpulan :

1. Penerapan metode debat aktif pada pembelajaran konsep dasar PKn mendorong mahasiswa untuk lebih aktif dalam berdiskusi karena setiap mahasiswa diberi kesempatan untuk berbicara dan berargumen secara logis. Serta adanya pembagian kelompok dengan topik dan sudut pandang yang berbeda. Melalui pengkondisian sedemikian rupa membuat diskusi tidak lagi didominasi oleh mahasiswa tertentu.

2. Penerapan metode debat aktif dapat meningkatkan kemampuan mahasiswa dalam berdiskusi hal ini Nampak dari peningkatan presentase pada siklus I dan II dimana pada siklus I presentase keaktifan yaitu $63,09 \%$ dikategorikan sedang, pada siklus II meningkat menjadi $89,97 \%$ masuk dalam kategori tinggi.

\section{DAFTAR PUSTAKA}

Arikunto, Suharsimi. 2014. Penelitian Tindakan Kelas. Jakarta: PT Bumi Aksara.

Branson, S,Margaret, et.al .1999.Belajar civic education dari Amarika. Yogyakarta: LKis

Bullatau.S.J.J. 2007. Teknik Diskusi Kelompok.Yokyakarta:Kanisius

Creswell, J. W. 2009. Research Design : Qualitative, quantitative, and mixed methods approaches. (edisi ketiga). Thousand Oaks : Sage.

Departemen Pendidikan Nasional. 2000.Kamus Besar Bahasa Indonesia. Jakarta: Balai Pustaka

Dipodjojo, Asdi.1982. Komunikasi Lisan. Yogyakarta: PD. Lukman

DoriWuwur, Henrikus. 1991. Retorika. Yogyakarta : Kanisius

Eurydice . 2005 Pendidikan kewarganegaraan - persepsi siswa Portugis (https://doi.org/10.1016/j.sbspro.2011.03 .367. di akses pada tanggal 11 Agustus 2015)

Fraenkel, J. R., Wallen, N. E. and Hyu, H. H. 2012. How to Design and Evaluate Research in Education. New York : McGraw-Hill.
Hendrikus, Dori Wuwur. 2009. Retorika terampi berpidato, Berdiskusi, Berargumentasi Bernegoisasi. Yokyakarta: Kanisius.

Herring, Jonathan, 2013.Cara Tepat Berdebat secara Cerdas, Meyakinkan, dan Positif. Jakarta:PT.Buana Ilmu Populer.

Hopkins, David (2008). A Teacher's Guide to Classroom Research Fourth edition. Philadephia: Open University Press

Juliani Ni Nyoman, 2013.Metode Debat Teknik Itemized Response untuk Meningkatkan Hasil belajar PKn (On Line) diakses tgl 28 Februari 2014.

Kamdhi, JS. 1995. Diskusi Yang Efektif. Cirebon : Kanisius

Kunandar. 2009. Langkah-langkah mudah PTK sebagai pengembangan profesi Guru. Jakarta:Rajawali Citra

Komalasari, Kokom. 2014. Pembelajaran Kontekstual. Bandung : Refika Aditama.

Koyan, I Wayan. 2000. Pendidikan Moral : Pendekatan Lintas Budaya. Jakarta : PPGSM Dirjen Dikti.

Lickona, T. 1992. Educating for Character, How Our Schools Can Teach Respect and Responsibility. New York : Bantam Books.

Musfiroh, Tadkiroatun. 2005. Bermain Sambil Belajar dan Mengasah Kecerdasan. Jakarta : Direktorat Jendral Pembinaan Pendidikan Tenaga Kependidikan.

Nurchabibah,2011.Keefektifan Metode Debat dalam Pembelaaran diskusi pada Kelas $X$ SMA Negeri Kutowinangun (On line) diakses tgl 28 Februari 2014.

Nurkancana,1986. Evaluasi Pendidikan. Surabaya. Usaha Nasional. Riyanto,Asul.2000, Terampil berdiskusi. Jakarta:Gramedia

Nogueira, Moreira. 2011. Pendidikan kewarganegaraan - persepsi siswa Portugis (https://doi.org/10.1016/j.sbspro.2011.03 367. di akses pada tanggal 11 Agustus 2015)

Silbermen,Malvin.L,2006.Acive Learning 101 Strategi pembelajaran Siswa Aktif. Bandung : Nusa Media

Slameto.2007.Belajar dan Faktor-Fakor Yang Mempengaruhi.Jakarta :Rineka cipta

Sugiyono. 2010. Metode Penelitian Pendidikan (Pendekatan Kuantitatif, Kualitatif, $R \& D$ ). Bandung: Alfabeta 
Tarigan Henry Guntur,2008.Berbicara sebagai suatu keterampilan berbahasa.

Bandung:Aksara

Tesfaye Semela. 2013. Pendidikan kewarganegaraan di sekolah-sekolah Ethiopia: Adopsi paradigma, teknologi instruksional, dan kewarganegaraan demokratis dalam konteks multicultural. (https://doi.org/10.1016/j.ijedudev.2012. 03.003 di akses pada tanggal 11 Agustus 2015)

Thorsten Bohl. 2013 Pendidikan kewarganegaraan di sekolah-sekolah Ethiopia: Adopsi paradigma, teknologi instruksional, dan kewarganegaraan demokratis dalam konteks multicultural. (https://doi.org/10.1016/j.ijedudev.2012. 03.003 di akses pada tanggal 11 Agustus 2015)

Trianto.2010. Model Pembelajaran Terpadu, Konsep, Strategi dan implementasinya dalam Kurikulum KTSP.Jakarta:Bumi Aksara.

Ubaedillah. 2015. Pendidikan Kewarganegaraan. Bandung : Refika Aditama. 